\title{
THE INFLUENCE OF GALLERY WALK MODEL TOWARDS STUDENTS' SPEAKING SKILL
}

\author{
ELIS ANDINI (a), SUNARA (b), SUMPENA ROHAENDI (c) \\ Pendidikan Bahasa Inggris, FKIP Universitas Subang
}

Elisnadini75@gmail.com

rasunaok@gmail.com

\author{
sumpenarohaendi07786@gmail.com
}

\begin{abstract}
The purpose of the researchwas to investigate whether or not the influence gallery walk model towards students speaking skill. The resarch was onducted in SMPN 2 Purwadadi. This research use Quantitative method and used non-equivalent control group design categorized as Quasi expeimental design. Two classes were selected from seventh as experiment and control class. The result of the data analysis were as follows. Mean score of pretest in experiment class was 15.66 and standard deviation was 2.057. while, mean score in control class was 16.25 and standard deviaton was 1.586 . further, mean score of posttest in experiment class was 17.81 and standard deviation was 1.533. while, mean score posttest in control class was 17.66 and standard deviation was 1.619. The result of T-test shows that value sig. (2-tailed) was 201 in pretest. It was higher than 0.05 . Then, there was not diffence of mean between experiment and control class in pretest. The value sig. (2-tailed) was 6.93 in posttest. It was higher than 0.05. Then, there was not difference of means between experiment and control class in posttest. Based on the result of model summary in simple regression, $R$ squere was 0.051 with significance 0.214. it means that the influence of independent variable (questionnaire) towards dependent variable (posstest) was $0.05 \%$. While, $99.95 \%$ influenced by other variable. Then model of regressing was not good enough as predictors. Based on the coefficient, constant of 20.308 if there was nothing questionnaire, then value of posttest is -0.046 . Regression coefficien $X$ of (-0.214) it means each addition 1 value of questionnaire then decline of posttest value of $(-0.214)$. it shows that there was not the significance influence of Gallery walk model toward students speaking skill.
\end{abstract}

Keywords: Gallery walk model, speaking skill

\section{INTRODUCTION}

Language is means to communicate in activity every day for any aspect of life, for that language makes it easier to undersatnd everything. Four basic english skills such as listening, speaking, reading and writing is very important thing for learning english. each base has a rank of variety difficulty, such as speaking many 
students who can not speaking english, in this case the author will discuss the reading skills of the four skills.

Speaking is important for them to practice their capability and understaning, how to send idea, and how to spell word well in this case the studens' motivation and interest are very needed to make the process of their understanding more easily.

Most students assume that speaking is something difficult in pronounciation. Actually, it makes them fearful and difficult to learn english, because they feel inadequate, sometimes students are so lazy and do not want when speaking English because they assume to speaking English was very difficult. Lack of interest of students attending english classroom make student's achievement low. It takes media that can stimulate the students enjoy participating in learning English.

The problems that be found SMPN 2 PURWADADI is low ability in learning English, the problem is caused by common problems such as lack of motivation, low ability in English. The problems influence their ability to learn English, especially in speaking skills

Appropriate instructional model is absolute necessity to stimulate children ability in learning english. Therefore the writer will try to apply the model learning through Gallery Walk "pameran berjalan". There are changes in the subjects of English achievement of students, especially students' speaking skill through such model.

The writer found that learning English in junior high scholl is very low. This condition eventually affects students' english speaking, because students consider learning English is something that makes them feel bored and afraid follow English language learning.the method used by the teacher is not in accordance with the submitted materials, so that students are not stimulated to following English language learning, and the effect si that students are afraid to speak English.

The problem is how influence of teaching speaking through Gallery Walk model From the brief description above researcher interested to take the tittle of "the influence of gallery walk model towards students' speaking skill".

The formulation of the problems is the started as follow:

1. Does the gallery walk model affect the speaking skill of the students?

\section{THEORITICAL REVIEW}

\section{The nature of speaking skill}

\section{a. The meaning of Skill}

According to Quirk (1987:101) skill is special ability to do something well that is obtained by learning and practicing. The same is suggested by fries that a person can be said to have skills is the person has the ability to act and perform certain actions with ease and only after going through the learning process (1945:-6-7). 
Gagne and briggs (1985:49) put skill as learning outcomes divided into five categories, (1) intellectual skill, (2) verbal information, (3) cognitive arrangement activity, (4) psychomotor skill and (5) attitudes. Whereas according to Richards (1985:160), skills is the style that language used .

Hence it is conclude that the skill is the ability to practice well done and produced from learning and practicing. The students or learners are said to be skilled as they have the abilit to do something expertly especially related to language.

\section{b. The meaning of speaking}

Florez in Bailey (2005:2) stated that speaking is an interactive process of contructing meaning that invloves producing and receiving and processing information. According to Bailey, speaking is the productive aural/oral skill which consists of producing systematic verbal utterances to convey meaning.

Speaking is an interactive process of contructing meaning that invloves producting,receivingand processing informstion. Its form and meaning are depend on the contex in which it occurs, including the participants themselves, their collective experiences, the physical environment and the purposes for speaking. Speaking requires that learners not only know how to produce speasific points of language such as grammar, pronounciation, or vocabulary ( linguistic competence ), but also they understand when, why and in what ways to produce language ( sociolinguistic comptence).

\section{Gallery Walk model}

Gallery walk is a presentation method in which individual learners or groups display their work products (often on posters) and then walk around the room viewing each other's work. They may be asked to provide feedback to the group of individual who created the work (Silberman, 1996: 24).From Silberman's statement means gallery walk allows students to be actively engaged as they walk throughout the classroom. They work together in small groups to share ideas and respond to meaningful questions, images, and problem-solving situations or texts.

In the other hand, Francek (2006: 27) describes that gallery walk is a discussion technique that gets students out of their chairs and into active engagement. The advantage of the method its flexibility. A Gallery walk holds a variety ofbenefits for students and teachers alike.

The gallery walk is a powerful opening, closing, or review activity. In this activity, participants write on various pieces of chart paper that they have taped to the training room walls. Through a gallery walk, the students are able to learn from one another and from their own previous knowledge. The technique serves many different types of students' intelligences and many different ways in which students 
learn. It serves the kinesthetic learner, because it involves walking around and other movement, it serves the interpersonal learner, because it includes small group interaction, and it serves the verbal/linguistic learner, because it includes discussion and written answers.

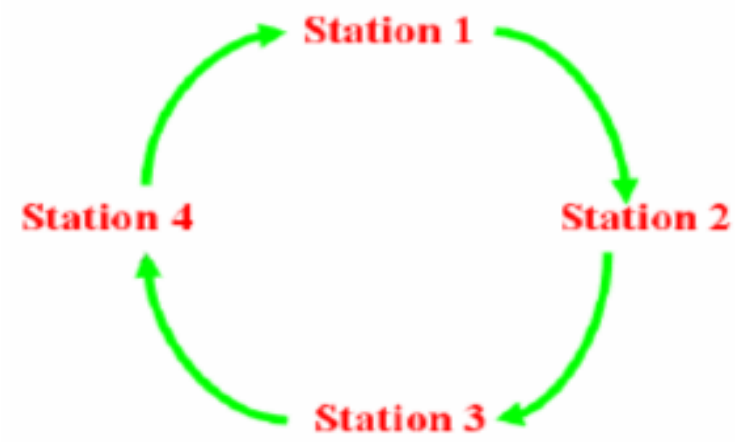

Figure 1: The Picture of Gallery Walk Technique

\section{a. Procedure of Gallery walk}

1. Select text

Select the text (e.g. quotations, images, documents, and/or student work) you will be using for the gallery.

2. Organize text around the classroom

Text should display "gallery style" in a way that allows students to disperse themselves around the room, with several students clustering around a particular text. Text can be hung on walls or placed on tables the most important factor is that the texts are spread for enough space to reduce significant crowding.

3. Instruct students on how to walk through the gallery

Instructions will depend on the goal for the activity. Students can take gallery walk on their own, or with a partner or in small groups, announcing when the group should move to the next place in the exhibit.the next place in the exhibit.

\section{b. The Steps of Gallery walk}

Francek (2006: 28) describes that the instructions will depend on the goals of teaching. In this research the goal of teaching by using gallery walk is to enhance students' self- confidence in speaking. So, ( Farah: 2015 ) modifies the teaching instructions on the teaching steps as follow:

1. The teacher provides some materials needed such as: several sheets or carton, glue, different colored pens and discussion questions.

2. The teacher divides the class into group with four or five students and give each group a different colored pen. 
3. The students make their gallery in group and discuss what they have in the gallery.

4. The teacher instructs each group to walk around to the next gallery. Every group have to review the task, discussion questions and any answer recorded by the previous groups. Then members of the group must add an informations or comments with a colored pen that represents their own group.

5. After an appropriate amount of time (about 3 minutes), the students move to other gallery until all the groups have visited each gallery.

6. The students return to their own gallery to prepare the comments and brief oral report to present in the larger class. These oral report as an opportunity for all the students to check their own understanding.

7. The teacher gives comments and summarize the discussion questions in the end of learning.

\section{c. The Benefits of Gallery walk}

According to Bowman (2005:94) explains a gallery walk can:

1. Connect learners to both new and old information;

2. Help learners focus on what they alread know and what they want to learn;

3. Build a strong learning community by connecting learners to each other and to the topic;

4. Provide learners with an opportunity to physically move around while reviewing material;

5. Provide time for learners to respond to the topic related issues that they might not otherwise have had the time to address; and

6. Act as an ice breaker because students interact with classmates and the teacher when debating responses at each gallery walk "station".

\section{d. Gallery walk model in Teaching Speaking}

Gallery walk is most successful when students are properlyprepared to use it, when instructors are familiar both in its effective useand challenges, and when student learning is assessed. Bowman (2005: 93)suggests the general instructions for teaching using gallery walk are asfollow:

1. Tape a number of large sheets of paper to the wall of the training room. Space the chart pages so that learners can walk from one chart toanother.

2. Label each chart with question, statement, or issue related to the topic.

3. Learners walk around the room writing their responses on the charts.

4. Assign a direction to move or they can move randomly. They can dothe activity as individuals or in groups.

5. After the learners have written on all the charts and jotting down theirobservations on a work sheet, learners then spend a short period oftime in small groups discussing their observation. 
6. Finally they discuss the activity with the whole group.

\section{RESEARCH METHODOLOGY}

This research used quantitative method and categirized as quasi experimental design. This research was to find out the influence of Gallery walk model toward students' speaking skill. Two class. Futhermore, this research used non equevalent control group design. In this case. Treatment of Gallery walk model only was given to experiment class. While, control class was given another treatment. The both of experiment and control class got the same material.technique of data collecting in this research were test (pretest -posttest), questionnaire and observation. Technique of data analysis. The test was done by using SPSS Vesion 20.

\section{THE RESULT OF RESEARCH}

\section{Quantitative data analysis}

In normality test, the significance value obtained pretest of experiment and control class were higher than 0.05 . it can be conclude that both experiment nad control class in pretest had normal distribution. Further, the significance value obtained posttest of experiment and control class were higher than 0.05. it can be conclude that both of experiment and control class had normal distribution. Pretest and posttest had normal distribution.

The result of homogeneity test between experiment and control class in pretest and posttest was higher than significance 0.05 . it means that scores between experiment and control class in pretest and posttest were homogeneous.

The value sig.(2-tailed) in pretest was higher than 0.05 . then, there was not difference of means between experiment control class in prettest. Furthermore, the value sig. (2-tailed) in posttest was higher than 0.05. then, yhere was not difference of means between experiment and control class in posttest.

Based on the model summary in simple linear regression test, $\mathrm{R}$ square was 0.51 with significance 0.226 . it means that the influence which was can explained of independent variable (questionnaire) towards dependent variable (posttest) was $0.05 \%$. while , $99.95 \%$ influnced by other variables. Then model of regression is not good enough as predictors. Based on the coeficient, constant of 20.308 . if there is nothing questinnaire, then value of posttest is 20.308. regression coeficient X of (-0.046), it means each addition 1 value of questionnaire then decline of posttest value of 0.046 . 
Based on the result of simple linear regression, there was not the significance influence of Gallery walk model towards students' speaking skill.

\section{Qualitative data}

Beside the result of calculation above, data analysis in this research supported by analysis attitude scale data. In addition to above data processing, data analyis ofthis research is also supported by the results of data analysis of the attitude scale.

Students response to learning speaking of using Gallery Walk model, as a whole the students interest and showed a positive response to learning by using Gallery Walk model with percentage of $90.625 \%$ it can be seen from the statement number 1, namely learning by using Gallery Walk model it makes easier and get idea in speaking. Most students showed positive response to the Gallery Walk.

\section{CONCLUSION}

In the experiment research the influence of Gallery Walk model toward students' speaking skill in SMPN 2 PURWADADI academic year 2018/2019 there is significant influence of Gallery Walk model toward students' speaking skill.

Based on the explain previous the research can answer the result of treatment. The researcher conclude that the use of Gallery Walk model in teaching English, especially in teaching speaking skill to the student SMPN 2 PURWADADI is able to improve students speaking skill. Based on the result hypothesis of pretest in normality test, the significant are 0.109 in class experimental and 0.090 in class control, so the data $\mathrm{H}_{0}$ is accepted, and in test homogeneity is accepted with significant $0.393 \mathrm{H}_{0}$ is accept after that T-Test result is 0.201 Equal variances assumed and Equal variances not assumed is 0.201 , so it can be conclude that there is student speaking skill in experiment class using Gallery Walk model better than class control.

Based on the result hypothesis of data posttest in normality test, the significant are 0.173 in class experimental and 0.145 in class control, so the data $\mathrm{H}_{0}$ is accepted and in test homogeneity is accepted with significant $0.741 \mathrm{H}_{0}$ is accepted after that T-Test result is 0.693 Equal variances assumed and Equal variances not assumed is 0.693 , so it can be conclude the result post can see that difference the data result pretest and post post test that there is student speaking skill in experiment class using Gallery Walk model better than class control.

Motivation the students with Gallery Walk model for learning proses van give motivation for make hard study in class, the result of motivation can support also with questionnare result in the end of learning prosses. 


\section{BILBIOGRAPHY}

Bowman, Sharon L. 2005. The Gallery Walk: An Opening, Closing, and Review Activity. Available at

Gagne.RM and Briggs. (1985). The Condition of Learning. New York. Holt

Rinehar and Wilson

Richards (1985:160) Revisiting the Concepts 'Approach', 'Design' and

'Procedure'[online]:[tersedia]:

https://files.eric.ed.gov/fulltext/ED537447.pdf [20 agustus 2018]

Silberman,M. L. (1996). Active Learning and Active-LearningBased Teaching Model.

Bandung:Nuansa.[online]:[terasedia]:

http://www.tintapendidikanindonesia.com/2018/07/mode

1-pembelajaran-gallery-walk-pameran.html [27 september 2018]

Silberman, M. L. (2006). Active Learning 101 Cara Belajar Siswa Aktif.

Bandung:Nuansa.[online]:[terasedia]:

http://www.tintapendidikanindonesia.com/2018/07/mode

1-pembelajaran-gallery-walk-pameran.html [27 september 2018]

Bailey, Khatleen M. (2005). Practical language teaching:speaking. New York:

McGraw Hill. 